\title{
PENGARUH KADAR RICE HUSK ASH TERHADAP KUAT TEKAN PADA HIGH STRENGTH SELF COMPACTING CONCRETE (HSSCC) BENDA UJI SILINDER 7,5 CM X 15 CM USIA 14 DAN 28 HARI.
}

\author{
Brilyan Gusmi Auliyaa Robbani'1), Wibowo' ${ }^{2)}$, Endah Safitri ${ }^{3)}$ \\ 1) Mahasiswa Program Studi Teknik Sipil, Fakultas Teknik, Universitas Sebelas Maret Surakarta \\ 2) 3) Pengajar Program Studi Teknik Sipil, Fakultas Teknik, Universitas Sebelas Maret Surakarta \\ Jalan Ir. Sutami 36A Surakarta 57126 Tlp 0271-647069, Email: brilyan.11a3.07@gmail.com
}

\begin{abstract}
As the field of construction develop, various innovations to modify concrete are popping up. High strength self-compacting concrete (HSSCC) or high quality concrete self-condensed solid is one of the innovations in the manufacture of concrete In Indonesia is currently doing a lot of research on the procurement of alternative materials as a mixer or replacement of cement in self compacting concrete. Chemical added materials used in this research is superplasticizer which is useful to improve concrete's workability, while the added mineral materials used is rice husk ash. Rice husk ash serves to increase the compressive strength of the concrete because its pozzolannic nature and high amount of silica elements.

This research was conducted to examine the effect of the addition of different levels of rice husk ash composition on high quality self compacting concrete. In this research, the content of SiO2 (silica) in rice husk ash is $84.91 \%$ and the variation of rice busk ash used is $0 \%, 5 \%, 7.5 \%, 10 \%$ and $12.5 \%$ compared to the weight of cement. The test specimens used are cylindrical in size $7.5 \mathrm{~cm}$ and beight $15 \mathrm{~cm}$. Tests conducted on self compacting concrete parameters are filling ability, passing ability and segregation resistance. Hard concrete tests were performed at 14 days and 28 days.

The results showed that concrete with $5 \%$ and $7.5 \%$ rice husk ash gave good result for the self compacting concrete parameters test. Optimum compressive strength occurred in 14 days old concrete is $29.72 \mathrm{MPa}$ with the addition of rice husk ash $9.33 \%$ and the Optimum compressive strength occurred in 28 days old concrete is $51.09 \mathrm{MPa}$ with the addition of rice husk ash 8.88\%.
\end{abstract}

Keyword : : high strength concrete, self compacting concrete, rice husk ash, bonding time, compressive strength

\begin{abstract}
Abstrak
Seiring dengan perkembangan zaman, semakin banyak pula pembangunan infrastruktur di dunia. Pada era teknologi sekarang ini, muncul berbagai inovasi untuk memodifikasi beton. High strength self compacting concrete (HSSCC) atau beton mutu tinggi memadat mandiri merupakan salah satu inovasi dalam pembuatan beton. Di Indonesia sendiri saat ini sedang banyak melakukan penelitian mengenai pengadaan bahan alternatif sebagai pencampur atau pengganti semen pada beton SCC. Bahan tambah kimia yang digunakan berupa superplasticizer yang berguna untuk memudahkan dalam pengerjaan beton (workabilityx), sedangkan bahan tambah mineral yang digunakan adalah rice busk ash (abu sekam padi). Abu sekam padi berfungsi untuk meningkatkan kuat tekan beton karena bersifat pozzolannik dan mengandung unsur silika tinggi.

Penelitian ini dilakukan untuk mengkaji pengaruh penambahan variasi komposisi rice husk ash pada beton mutu tinggi memadat mandiri. Dalam penelitian ini kandungan $\mathrm{SiO}_{2}$ (silika) pada abu sekam padi sebesar 84,91\% dan kadar variasi abu sekam padi yang digunakan sebesar $0 \%, 5 \%, 7,5 \%, 10 \%$ dan $12,5 \%$ terhadap berat semen. Benda uji yang digunakan berbentuk silinder berukuran $7,5 \mathrm{~cm}$ dan tinggi $15 \mathrm{~cm}$. Pengujian yang dilakukan terhadap parameter self compacting concrete yaitu fillingability, passingability dan segregation resistance serta pengujian kuat tekan beton pada umur 14 dan 28 hari dengan menggunakan Universal Testing Machine (UTM).

Hasil penelitian menunjukkan bahwa beton dengan kadar variasi 5\% dan 7,5\% abu sekam padi memberikan hasil yang baik untuk pengujian terhadap parameter self compacting concrete dan kuat tekan optimum pada beton umur 14 hari adalah 29,72 MPa pada kadar abu sekam padi 9,33\%, sedangkan kuat tekan optimum pada beton umur 28 hari adalah 51,09 MPa pada kadar abu sekam padi 8,88\%.
\end{abstract}

Kata Kunci : beton mutu tinggi, beton memadat mandiri, abu sekam padi, waktu ikat, kuat tekan 


\section{PENDAHULUAN}

High strength self compacting concrete (HS-SCC) atau beton mutu tinggi memadat mandiri merupakan salah satu inovasi dalam pembuatan beton. Beton HS-SCC ini memiliki kemampuan dalam mengisi ruang-ruang (fillingability) karena kemudahan materialnya dalam mengalir (flowability) karena sifat kecairan (fluidity) yang tinggi. Kemampuan beton HS-SCC dalam mengisi ruang dapat memudahkan dalam pengerjaan sehingga dapat dilakukan tanpa proses pemadatan menggunakan bantuan alat pemadat.

Kriteria beton mutu tinggi berubah-ubah sering dengan perkembangan teknologi. Pada tahun 1950, beton dengan kuat tekan $30 \mathrm{MPa}$ sudah dikategorikan sebagai beton mutu tinggi. Pada tahun 1960 hingga awal 1970, kriterianya naik menjadi $40 \mathrm{MPa}$. Saat ini, beton dikategorikan mutu tinggi apabila kuat tekannya diatas 50MPa, sedangkan untuk $80 \mathrm{MPa}$ dikategorikan sebagai beton mutu sangat tinggi, dan untuk $120 \mathrm{MPa}$ bisa dikategorikan sebagai beton bermutu ultra tinggi (Supartono, 1998).

Sekam padi merupakan hasil samping dari penggilingan padi yang berupa kulit terluar dari biji padi. Selama ini pemanfaatan sekam padi pada umumnya hanya sebagai bahan bakar dalam proses pembakaran gerabah ataupun briket sekam. Pemanfaatan sekam sebagai bahan bakar akan menghasilkan hasil samping yang berupa abu sekam. Selama proses perubahan sekam padi menjadi abu, pembakaran menghilangkan zat-zat organik dan meninggalkan sisa pembakaran yang mengandung silika ( $\mathrm{SiO} 2)$.

Kandungan silika yang tinggi serta karakteristik abu sekam padi yang cukup halus menjadi dasar penggunaan abu sekam padi sebagai bahan tambah dalam campuran beton. Pengguanaan abu sekam padi sebagai bahan tambah merupakan upaya dalam meningkatkan kinerja beton serta pemanfaatan limbah pembakaran sekam padi. Pengaruh kedua sebagai bahan pozolan, dimana $\mathrm{SiO} 2$ bereaksi dengan $\mathrm{Ca}(\mathrm{OH}) 2$ yang merupakan bahan sisa dari hasil hidrasi semen. Hasil reaksi keduanya menghasilkan kalsium silikat hidrat (CSH) sebagaimana yang dihasilkan hidrasi semen yang memberikan kekuatan pada beton kerasnya. Reaksi tersebut tersebar merata pada seluruh tempat di dalam beton termasuk pada ruang-ruang kosong pada lapisan agregat-pasta semen, sehingga menambah kekuatan lekatan antara agregat dan pasta semen.

Okamura and Ozawa (1995), mengusulkan metode mix design sederhana untuk SCC dengan spesifikasi bahan yang digunakan yaitu volume agregat kasar kurang dari 50\% dari volume total, volume agregat halus $40 \%$ dari volume mortar, faktor air semen (w/c) yang ditetapkan rendah, dan dosis superplasticizer dan faktor w/b ditentukan setelahnya untuk memastikan kepadatannya. Berdasarkan Tabel 1, EFNARC (2005) merekomendasikan range komposisi beton SCC untuk permeter kubiknya seperti di bawah ini.

Tabel 1. Mix Design yang Disarankan oleh EFNARC (2005)

\begin{tabular}{ccc}
\hline Bahan Material & Range dalam massa $\mathbf{( k g / \mathbf { m } ^ { 3 } )}$ & Range dalam volume (liter $\left./ \mathbf{m}^{3}\right)$ \\
\hline Powder & $380-600$ & $300-380$ \\
\hline Pasta & $150-210$ & $150-210$ \\
\hline Air & $750-1000$ & $270-360$ \\
\hline Agregat Kasar & $48 \%-55 \%$ dari total berat agregat \\
\hline Agregat Halus & & $0,85-1,10$ \\
\hline Rasio w/b dari volume & &
\end{tabular}




\section{METODE}

\section{Rancang Campur (Mix Design)}

Komposisi jumlah agregat yang digunakan tiap $1 \mathrm{~m} 3$ beton dapat dilihat pada Tabel 2

Tabel 2. Komposisi jumlah agregat yang digunakan tiap $1 \mathrm{~m} 3$ beton

\begin{tabular}{|c|c|c|c|c|c|c|c|}
\hline Kode. & $\begin{array}{l}\text { Kadar } \\
R H A\end{array}$ & $\begin{array}{l}\text { Ag. Kasar } \\
\left(\mathrm{kg} / \mathrm{m}^{3}\right)\end{array}$ & $\begin{array}{c}\text { Ag. } \\
\text { Halus } \\
\left(\mathrm{kg} / \mathrm{m}^{3}\right)\end{array}$ & $\begin{array}{c}\text { Semen } \\
\left(\mathrm{kg} / \mathrm{m}^{3}\right)\end{array}$ & $\begin{array}{c}R H A \\
\left(\mathrm{~kg} / \mathrm{m}^{3}\right)\end{array}$ & $\begin{array}{c}\text { Air } \\
\left(1 \mathrm{l} / \mathrm{m}^{3}\right)\end{array}$ & $\begin{array}{c}\mathrm{SP} \\
\left(1 \mathrm{t} / \mathrm{m}^{3}\right)\end{array}$ \\
\hline $\begin{array}{c}\text { Bscc - RHA } \\
0 \%\end{array}$ & $0 \%$ & 801,25 & 916,32 & 550 & 0 & 165 & 4,13 \\
\hline $\begin{array}{c}\text { Bscc - RHA } \\
5 \%\end{array}$ & $5 \%$ & 801,25 & 885,59 & 522,5 & 27,5 & 165 & 4,13 \\
\hline $\begin{array}{c}\text { Bscc - RHA } \\
7,5 \%\end{array}$ & $7,5 \%$ & 801,25 & 870,23 & 508,75 & 41,25 & 165 & 4,13 \\
\hline $\begin{array}{c}\text { Bscc - RHA } \\
10 \%\end{array}$ & $10 \%$ & 801,25 & 854,87 & 495 & 55 & 165 & 4,13 \\
\hline $\begin{array}{c}\text { Bscc - RHA } \\
12,5 \%\end{array}$ & $12,5 \%$ & 801,25 & 839,50 & 481,25 & 68,75 & 165 & 4,13 \\
\hline
\end{tabular}

Pada Tabel 2 dapat dilihat bahwa penambahan kadar Rice Husk. Ash mempengaruhi berat agregat halus dan semen, tetapi tidak mempengaruhi berat air, superplasticizer, dan agregat kasar pada komposisi tiap $1 \mathrm{~m} 3$ beton.

\section{Pengujian Beton Segar}

Pengujian beton segar dilakukan terhadap parameter dari SCC yaitu fillingability, passingability, dan segregation resistance. Adapun pengujian-pengujian tersebut berupa Flow Table Test, L-Box Test, dan V-Funnel Test.

\section{Pengujian Beton Keras}

Pengujian yang dilakukan terhadap beton keras adalah pengujian kuat tekan beton dengan menggunakan Universal Testing Machine (UTM) pada umur beton 14 hari dan 28 hari. 


\section{HASIL DAN PEMBAHASAN}

\section{Pengujian Beton Segar}

Hasil pengujian beton segar untuk masing-masing kadar rice husk ash dapat dilihat pada Tabel 3

dibawah ini.

Tabel 3. Hasil Pengujian Beton Segar

\begin{tabular}{|c|c|c|c|c|c|c|c|c|c|c|}
\hline \multirow[b]{2}{*}{ Kode } & \multicolumn{3}{|c|}{ Flow Table Test } & \multicolumn{3}{|c|}{ L-Box Test } & \multicolumn{4}{|c|}{ V-Funnel Test } \\
\hline & $\begin{array}{l}\mathrm{d}_{\text {rerata }} \\
(\mathrm{mm})\end{array}$ & $\begin{array}{l}\text { Syarat } \\
(\mathrm{mm})\end{array}$ & $\begin{array}{l}\mathrm{T}_{500} \\
(\mathrm{~s})\end{array}$ & $\begin{array}{c}\text { Syarat } \\
\text { (s) }\end{array}$ & $\mathrm{h}_{2} / \mathrm{h}_{1}$ & $\begin{array}{l}\text { Syarat } \\
\mathrm{h}_{2} / \mathrm{h}_{1}\end{array}$ & $\begin{array}{l}\text { Waktu } \\
\text { Aliran } \\
\text { Awal } \\
/ \mathrm{T}_{\text {awal }} \\
\text { (s) }\end{array}$ & $\begin{array}{c}\text { Syarat } \\
\mathrm{T}_{\text {awal }} \\
\text { (s) }\end{array}$ & $\begin{array}{c}\text { Waktu } \\
\text { Aliran } 5 \\
\text { menit } \\
/ \mathrm{T}_{5 \min }(\mathrm{s})\end{array}$ & $\begin{array}{l}\text { Syarat } \\
\mathrm{T}_{5 \min } \\
(\mathrm{s})\end{array}$ \\
\hline Bscc & & 650 & & & & 0,8 & & & & \\
\hline $\begin{array}{c}\text { - RHA } \\
0 \%\end{array}$ & 665 & $\begin{array}{c}- \\
800\end{array}$ & 3,1 & $2-5$ & 1,000 & - & 8,30 & $8-12$ & 12,21 & +3 \\
\hline Bscc & & 650 & & & & 0,8 & & & & \\
\hline $\begin{array}{l}\text { - RHA } \\
5 \%\end{array}$ & 685 & $\begin{array}{c}- \\
800\end{array}$ & 4,99 & $2-5$ & 0,994 & - & 10,23 & $8-12$ & 15,73 & +3 \\
\hline$\overline{\text { Bscc }}$ & & 650 & & & & 0,8 & & & & \\
\hline $\begin{array}{l}\text { - RHA } \\
\mathbf{7 , 5 \%}\end{array}$ & 680 & $\begin{array}{c}- \\
800\end{array}$ & 5,2 & $2-5$ & 0,941 & 1,0 & 14,29 & $8-12$ & 21,69 & +3 \\
\hline Bscc & & 650 & & & & 0,8 & & & & \\
\hline $\begin{array}{l}- \text { RHA } \\
10 \%\end{array}$ & 660 & $\begin{array}{c}- \\
800\end{array}$ & 5,53 & $2-5$ & 0,929 & - & 19,9 & $8-12$ & 25,77 & +3 \\
\hline Bscc & & 650 & & & & 0,8 & & & & \\
\hline $\begin{array}{c}\text { - RHA } \\
12,5 \%\end{array}$ & 645 & $\begin{array}{c}- \\
800\end{array}$ & 5,83 & $2-5$ & 0,857 & - & 22,84 & $8-12$ & 32,86 & +3 \\
\hline
\end{tabular}

Pada Tabel 3 dapat dilihat bahwa penambahan Rice Husk Ash berpengaruh pada diameter sebaran dan waktu pada Flow Table Test, semakin besar penambahan Rice Husk Ash akan memperlambat waktu alir beton segar tesebut sehingga mempengaruhi diameter sebaran beton segar. Pada L-Box Test, penambahan Rice Husk Ash akan mempengaruhi rasio h2/h1 karena gerak beton segar semakin lambat. Penambahan Rice Husk Ash mempengaruhi waktu T awal dan T 5 menit, semakin besar penambahan Rice Husk Ash maka semakin besar pula waktu T awal dan T 5 menit karena penambahan Rice Husk Ash akan meningkatkan kekentalan beton segar sehingga memperlambat gerak beton segar. 
Flow Table Test

Hasil pengujian Flow Table dapat dilihat pada Gambar 1. Dan Gambar 2. berikut.

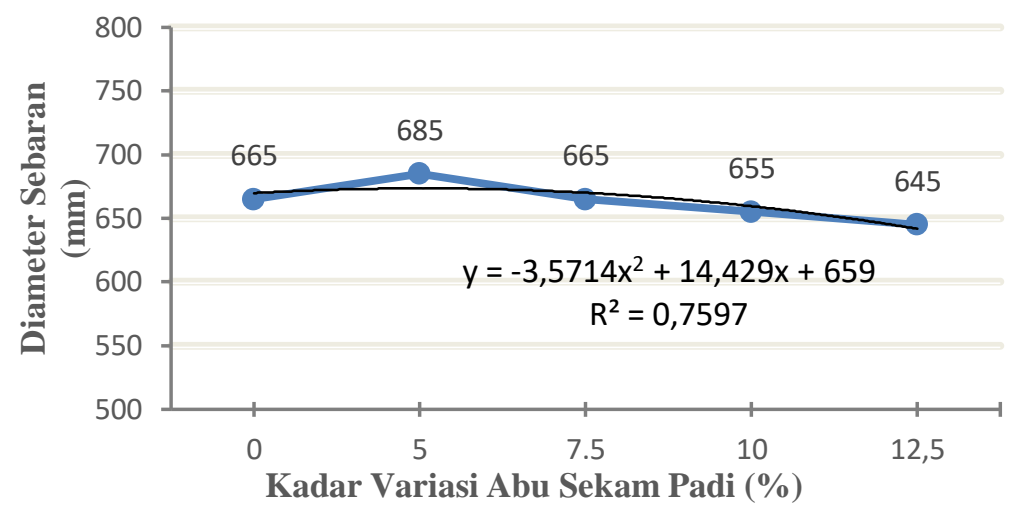

Gambar 1. Grafik Diameter Sebaran Flow Table Test dengan Kadar Rice Husk Ash

Berdasarkan Gambar 1. beton dengan variasi kadar Rice Husk. Ash 5\% memiliki diameter tertinggi sebesar 685mm jika dibandingkan dengan variasi kadar lainnya. Untuk kadar Rise Husk. Ash 10\% diameter sebarannya adalah 680 $\mathrm{mm}$. Adanya penurunan diameter sebaran dipengaruhi oleh kekentalan (viskositas) dari campuran tersebut. Semakin kecil diameter sebaran maka kekentalannya semakin tinggi dan semakin besar diameter sebaran maka kekentalannya semakin rendah. Rice Husk Ash memberikan pengaruh kekentalan yang baik pada campuran beton.

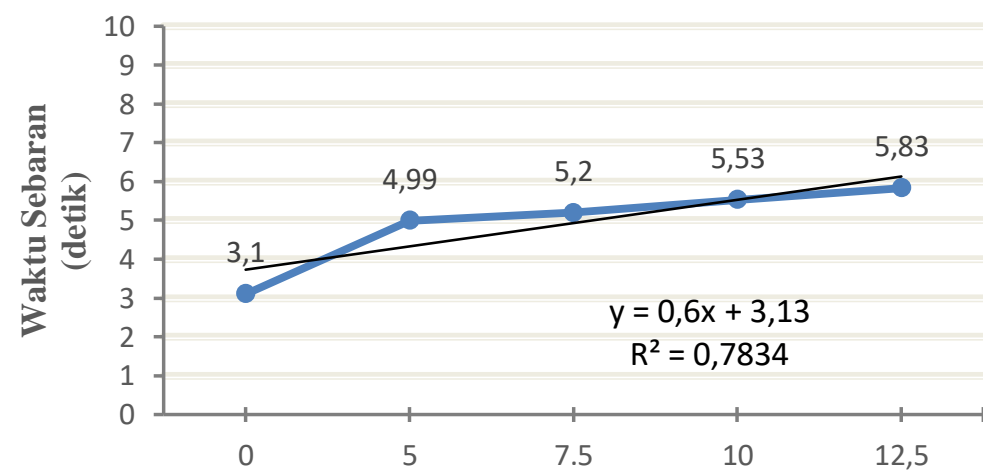

Kadar Variasi Abu Sekam Padi (\%)

Gambar 2. Grafik T500 pada Flow Table Test dengan Kadar Rice Husk Ash

Berdasarkan Gambar 2 maka semakin tinggi kadar Rice Husk Ash yang digunakan, jumlah air akan berkurang karena Rice Husk Ash akan lebih banyak menyerap air sehingga campuran yang dihasilkan akan lebih kental. Hal ini sesuai dengan pernyataan Ouchi et al (1998) yang mengatakan bahwa fungsi filler selain mengisi ruang kosong juga meningkatkan kekentalan dari campuran beton agar campuran terhindar dari segregasi. Semakin tinggi kadar yang digunakan maka waktu yang dibutuhkan beton mencapai $t_{500}$ akan semakin lama karena beton memiliki kekentalan yang lebih tinggi. Hal ini sejalan dengan penelitian yang dilakukan oleh Tangtermsirikul dan Khayat (2000) bahwa jika kekentalan beton semakin tinggi maka waktu pengalirannya juga akan semakin lama. 


\section{L-Box Test}

Hasil pengujian L-Box dapat dilihat pada Gambar 3. Dan Gambar 4. berikut.

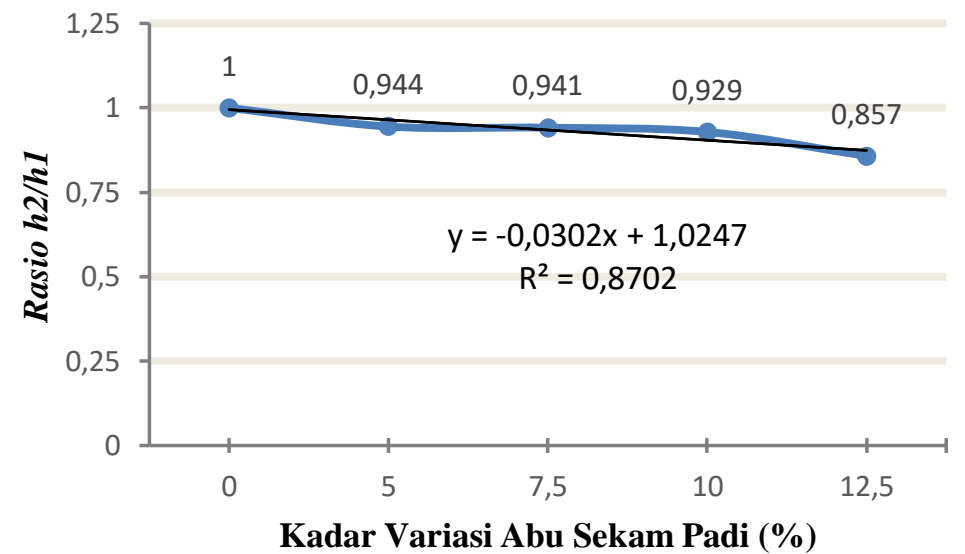

Gambar 3. Grafik h2/h1 pada L-Box Test dengan Kadar Rice Husk. Ash

Berdasarkan Gambar 3, Rice Husk Ash dengan variasi kadar $0 \%$ memiliki nilai $\mathrm{h}_{2} / \mathrm{h}_{1}$ yang paling optimum yaitu sebesar 1. Hal ini menunjukan bahwa pada kadar Rice Husk Ash o\% memiliki kemampuan untuk mengisi ruangan dan perataan permukaan campuran yang lebih baik. Pada kadar Rice Husk ash 9\% nilai h2/h1 sebes0,857. hal ini menunjukan penurunan dari pada hasil sebelumnya, namun masih memenuhi persyaratan. Untuk kadar Rice Husk Ash 10\% dan 11\% nilai $\mathrm{h}_{2} / \mathrm{h}_{1}$ adalah 0,786 dan 0,750. Dapat dilihat bahwa pada penambahan kadar ini nilai $\mathrm{h}_{2} / \mathrm{h}_{1}$ menurun drastis dan tidak memenuhi persyaratan yang ditentukan oleh EFNARC (2002). Beton yang memiliki kekentalan rendah akan lebih mudah mengalir dari prisma vertikal menuju prisma horizontal melalui tulangan dengan baik hingga mencapai stabilitas perataan permukaan, begitu pula sebaliknya. Pada pengujian ini, semakin tinggi kadar Rice Husk. Ash maka nilai $\mathrm{h}_{2} / \mathrm{h}_{1}$ akan menurun. Kadar Rice Husk Ash yang tinggi akan meningkatkan kekentalan campuran beton sehingga energi yang digunakan untuk melawan gesekan/friksi berkurang dan berakibat pada waktu pengaliran beton yang semakin meningkat.

\section{V-Funnel Test}

Hasil pengujian $V$-Funnel dapat dilihat pada Gambar 5. berikut.

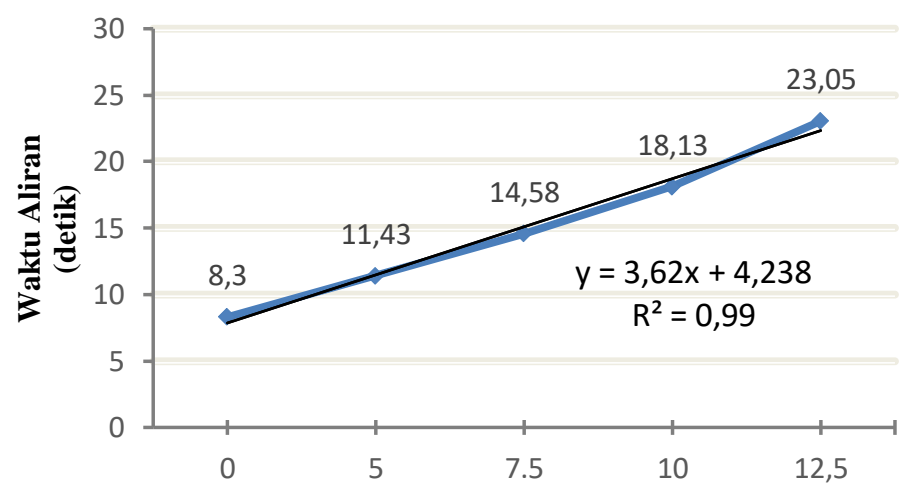

Kadar Variasi Abu Sekam Padi (\%)

Gambar 4. Grafik Hubungan Waktu Aliran pada V-funnel Test dengan Kadar Rice Husk Ash

Berdasarkan Gambar 4 dapat diketahui bahwa semakin tinggi kadar Rice Husk Ash maka waktu yang dibutuhkan campuran untuk mengalir semakin besar dikarenakan campuran beton memiliki kekentalan yang tinggi. Kekentalan yang tinggi ini disebabkan karena penggunaan Rice Husk Ash dapat mengurangi kadar air pada beton segar. 


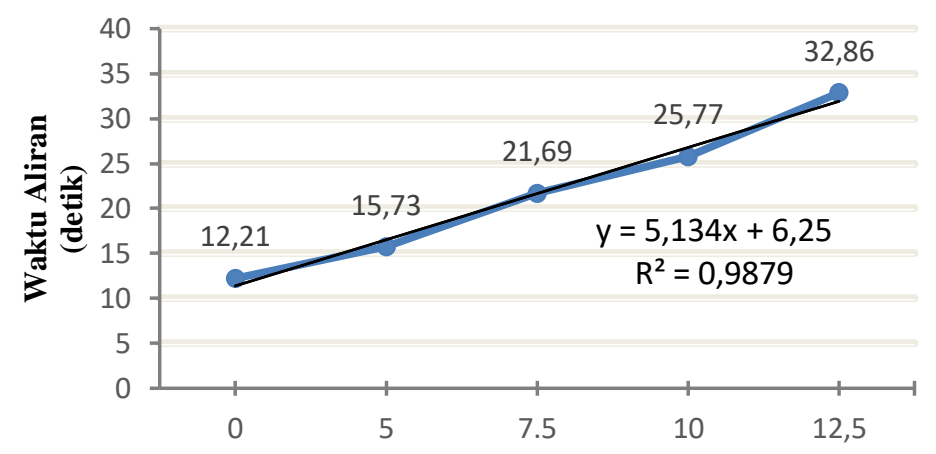

Kadar Variasi Abu Sekam Padi (\%)

Gambar 5. Grafik Hubungan Waktu Aliran pada $V$-funnel Test 5 menit dengan Kadar Rice Husk. Ash

Berdasarkan Gambar 5, kadar Rice Husk Ash 12,5\% membutuhkan waktu alir yang paling lama yaitu 23,05 detik untuk tertuang habis dari alat uji v-funnel, sedangkan $\mathrm{T}_{5 \min }$ membutuhkan waktu 32,86 detik. Untuk kadar Rice Husk Ash yang hampir memenuhi seluruh persyaratan baik itu waktu alir awal maupun $\mathrm{T}_{5 \min }$ adalah kadar $10 \%$ dengan waktu alir awal 8,65 detik dan $\mathrm{T}_{5 \min }$ sebesar 11,88 detik. Dari gambar diatas dapat diketahui bahwa semakin tinggi kadar Rice Husk. Ash maka waktu yang dibutuhkan campuran untuk mengalir semakin besar dikarenakan campuran beton memiliki kekentalan yang tinggi. Dengan tidak terpenuhinya syarat waktu pengaliran pada $\mathrm{T}_{5 \mathrm{~min}}$ yaitu sebesar +3 detik dari waktu pengaliran awal maka beton dengan kadar Rice Husk Ash 5\%, 7,5\%, 10\% dan 12,5\% mengindikasikan terjadinya segregasi.

\section{Pengujian Beton Keras}

Hasil pengujian kuat tekan beton pada silinder berukuran 7,5x15 cm dengan umur 14 hari dan 28 hari selengkapnya disajikan dalam Tabel 4, sedangkan Gambar 6 menunjukkan perbandingan kuat tekan umur 14 dan 28 hari.

Tabel 4. Hasil Kuat Tekan Beton Umur 14 dan 28 Hari

\begin{tabular}{lcc}
\hline \multicolumn{1}{c}{ Kode } & $\begin{array}{c}\text { Kuat Tekan 14 Hari } \\
\mathbf{( M P a )}\end{array}$ & $\begin{array}{c}\text { Kuat Tekan 28 Hari } \\
\mathbf{( M P a )}\end{array}$ \\
\hline Bscc- RHA 0\% & 34,49 & 40,57 \\
\hline Bscc- RHA 5\% & 21,28 & 42,31 \\
\hline Bscc- RHA 7,5\% & 27,37 & 44,59 \\
\hline Bscc- RHA 10\% & 30,31 & 55,37 \\
\hline Bscc- RHA 12,5\% & 24,84 & 40,32 \\
\hline
\end{tabular}

Pada Tabel 4 dapat dilihat bahwa dengan adanya substitusi Rice Husk Ash maka kekuatan tekan beton akan semakin bertambah jika dibandingkan dengan beton yang tidak mengandung Rice Husk. Ash. Hal ini terjadi karena Rice Husk. Ash memiliki peran ganda pada campuran beton yaitu sebagai filler dan pozzolan. Rice Husk. Ash mampu berperan sebagai filler yang mengisi ruang kosong diantara agregat dan pasta semen. Dengan berkurangnya ukuran pori dalam beton, maka diperlukan tekanan yang lebih tinggi untuk memulai retakan sehingga kekuatan beton akan meningkat. 


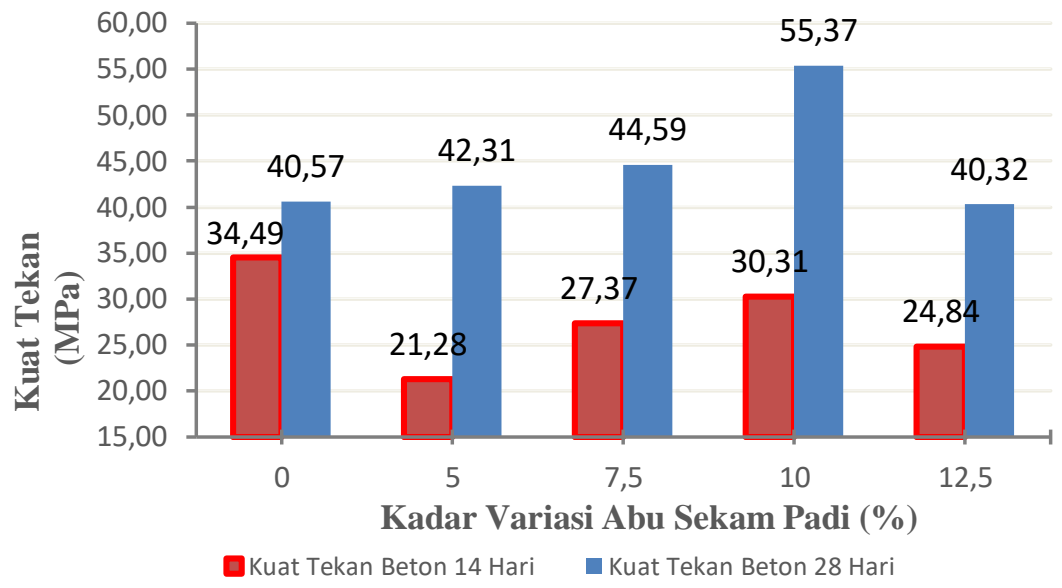

Gambar 6. Grafik Hubungan Kuat Tekan Beton dengan Kadar Rice Husk, Ash pada Umur Beton 14 dan 28 Hari

Berdasarkan Gambar 6. kuat tekan beton yang tidak disubstitusikan dengan Rice Husk Ash (Bscc RHA-0\%) pada umur 28 hari memiliki kuat tekan sebesar 40,57 MPa.

Rice Husk Ash memberikan dampak pada peningkatan kuat tekan beton seiring bertambahnya waktu. Pada kadar tertentu kuat tekan beton dengan Rice Husk Ash akan mengalami penurunan. Adanya penurunan kuat tekan beton setelah penambahan suatu kadar tertentu dikarenakan sifat Rice Husk. Ash yang menyerap air sehingga kandungan air didalam beton berkurang dan berdampak pada nilai w/b yang menjadi kecil. Nilai w/b yang kecil tidak selalu meningkatkan kuat tekan beton, akan tetapi pada suatu nilai w/b tertentu akan membuat kuat tekannya menurun.

Untuk mengetahui nilai optimum kuat tekan optimum dari kadar Rice Husk Ash yang digunakan maka disajjikan Gambar 7. sebagai berikut

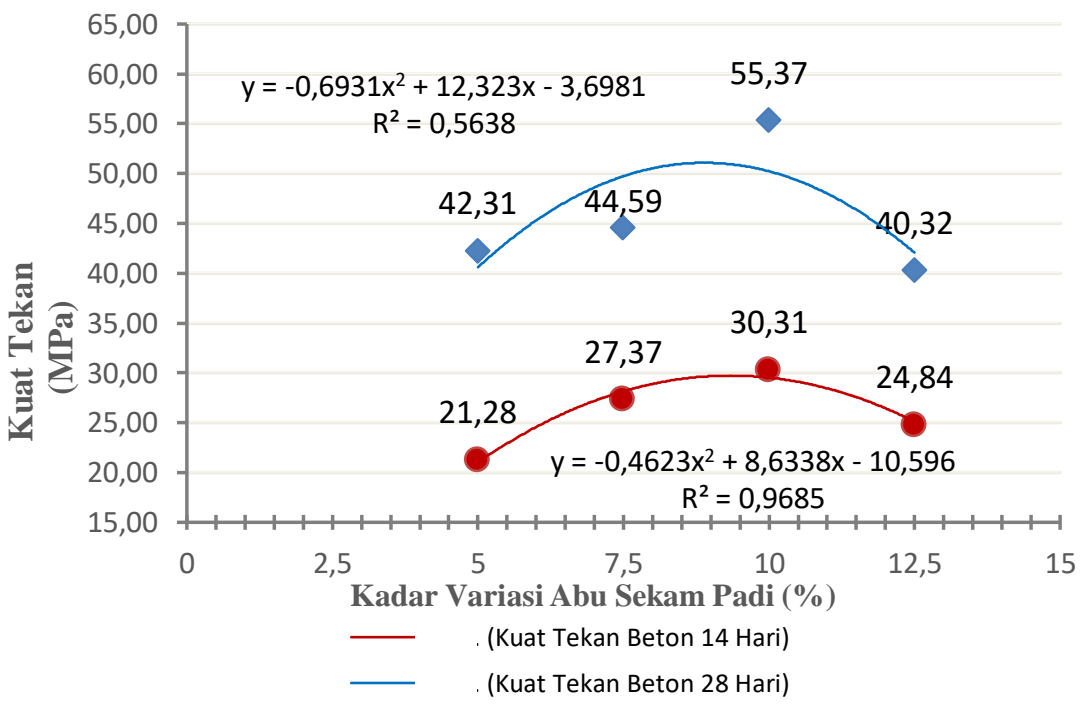

Gambar 7. Analisis Regresi Kuat Tekan Beton

Berdasarkan Gambar 7. diperoleh persamaan kuadratik untuk kuat tekan beton pada umur 14 hari dan 28 hari. Dari persamaan-persamaan kuadratik ini nantinya akan diperoleh persentasi kadar Rice Husk Ash yang menghasilkan kuat tekan optimum. Persamaan kuadratik untuk kuat tekan umur 14 hari adalah y $=-0.4623 \mathrm{x}^{2}+$ 8.6338x - 10.596 sehingga nilai kuat tekan optimum terjadi pada kadar silica fume sebesar 9,33\% dengan kuat tekan optimum sebesar 29,72 MPa.

Untuk kuat tekan 28 hari persamaan kuadratiknya adalah y $=-0.6931 \mathrm{x}^{2}+12.323 \mathrm{x}-3.6981$ sehingga nilai kuat tekan optimum berada pada kadar silica fume sebesar 8,88\% dengan kuat tekan optimum sebesar 51,09 MPa. 


\section{KESIMPULAN}

Dari hasil pengujian, analisis data, dan pembahasan, maka dapat ditarik beberapa kesimpulan yaitu:

a) Penggantian semen dengan kadar Rice Husk Ash memberikan hasil yang kurang baik karena tidak dapat memenuhi seluruh parameter SCC. Semakin tinggi kadar Rice Husk. Ash yang disubstitusikan maka kemampuan mengalir beton akan semakin berkurang karena beton akan semakin kental (viscous),

b) Beton SCC dengan Rice Husk. Ash memiliki kuat tekan yang lebih tinggi jika dibandingkan dengan beton SCC yang tidak menggunakan Rice Husk. Ash, baik pada umur 28 hari,

c) Kuat tekan beton optimum pada umur 14 hari adalah sebesar 29,72 MPa terjadi pada kadar Rice Husk Ash sebesar 9,33\% dan pada umur 28 hari sebesar 51,09 MPa terjadi pada kadar Rice Husk. Ash 8,88\%.

\section{REFERENSI}

EFNARC. (2002). Specification and Guidelines for Self-Compacting Concrete.

EFNARC. (2005). The European Guidelines for Self-Compacting Concrete Specification, Production and Use.

Okamura, H., and Ozawa, K. (1995). Self-Compactable High Performance Concrete. American Concrete Institute, Detroit.

Supartono, FX. (1998). Beton Berkinerja Tinggi dan Keterkaitannya Dengan Pembangunan Nasional Memasuki Abad 21. Seminar Material Konstruksi di Jurusan Sipil FTUI, Jakarta, 24 Maret 1998.

Tangtermsirikul, S and Khayat, K. (2000). "Part III: Fresh concrete properties", in: A. Skarendahl, O. Petersson (Eds.), Self-Compacting Concrete, State-of-the-Art Report of RILEM Technical Committee, 17-22. 